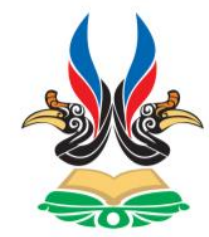

SPECTA Journal of Technology

E-ISSN : 2622-9099

P-ISSN : 2549-2713

Homepage jurnal: https://journal.itk.ac.id/index.php/sjt

\title{
Comparative Study of Open Frame Structure Modeling with Diagonal Bracing at the Integrated Laboratory of Institut Teknologi Kalimantan
}

\author{
Christianto Credidi Septino Khala ${ }^{1}$, Andina Prima Putri ${ }^{2}$, Oryza Lhara Sari ${ }^{3}$ \\ ${ }^{1,2,3}$ Departement of Civil Engineering, Institut Teknologi Kalimantan, Balikpapan. \\ Email: chris.csk@lecturer.itk.ac.id
}

\begin{abstract}
Generally, brick wall (hebel) is considered as non-structural element, which never be counted to bear structural load. But, if carefully calculated, brick walls take part in structure load bearing. In the purpose of reducing the main structural element properties, the brick wall needs to be considered in bearing structural load. In this article, the brick walls modelled as compressive bracings. Using the structure analysis program, the model showed some significant differences in terms of internal force. From the analysis, the differences of moment, shear, axial and torsional force between open frame model (usual model, OF) and compressive bracing (CB) model were 38.17 kN.m; $58.03 \mathrm{kN} ; 181.75 \mathrm{kN}$ dan $44.18 \mathrm{kN} . \mathrm{m}$, respectively, where the first model had the bigger numbers than the latter model. Displacement of OF model was quite larger than CB model, with the value of difference was up to $85.35 \%$ for the $\mathrm{X}$ direction structures, and $70.83 \%$ for the $\mathrm{Y}$ direction. Final properties used for the design are smaller compared than original design, 30/60 to 40/60 for the beams, 50/50 for the columns with the different reinforcements 16-D22 for the second model compared to 20-D22 for the first one. The depth of slab on the second model was $180 \mathrm{~mm}$, slightly smaller than the first model, $190 \mathrm{~mm}$. It can be concluded that using compressive bracing model, structural properties of ITK Integrated Laboratory Building may greatly be reduced, compared to OF model.
\end{abstract}

Keywords: compressive bracing, displacement, infilled brick-wall, internal force, open frame.

\begin{abstract}
Abstrak
Dinding bata pada saat perencanaan dianggap sebagai elemen non-struktural yang tidak diperhitungkan untuk memikul beban tetapi pada kenyataannya, dinding bata juga menyumbang kekuatan untuk memikul beban pada struktur tersebut. Untuk mengefisiensi dimensi pakai elemen utama seperti balok, kolom dan pelat serta mengetahui perbedaan gaya dalam, displacement dan dimensi penampang akhir maka dilakukan kajian untuk memodelkan struktur dengan dinding pengisi menggunakan model diagonal tekan. Hasil yang didapatkan ialah gaya momen, geser, aksial dan torsi model open frame $(O F)$ lebih besar dibandingkan model diagonal tekan (DT) dengan selisih perbandingan berturut-turut sebesar $38.17 \mathrm{kNm}, 58.03 \mathrm{kN}, 181.75 \mathrm{kN}$ dan $44.18 \mathrm{kNm}$. Nilai displacement model OF lebih besar dibandingkan model DT dengan selisih arah X untuk tingkat atap sebesar $85.35 \%$ dan arah $Y$ sebesar $70.83 \%$. Dimensi akhir penampang yang didapatkan pada model DT cenderung lebih kecil yaitu 30/60 dibandingkan model OF yaitu 40/60 pada elemen balok. Pada elemen kolom, dimensi DT adalah 50/50 dengan tulangan 16-D22 dan pada OF adalah 50/50 dengan tulangan 20-D22. Tebal pelat DT juga lebih kecil yaitu $180 \mathrm{~mm}$ dibandingkan model OF sebesar $190 \mathrm{~mm}$. Dari hasil studi dapat disimpulkan, dengan menggunakan pemodelan struktur DT dapat mengefisiensi penampang pada struktur gedung Laboratorium Terpadu ITK dibandingkan dengan pemodelan OF.
\end{abstract}

Kata Kunci: diagonal tekan, dinding pengisi, gaya dalam, perpindahan, portal terbuka. 


\section{Introduction}

Institut Teknologi Kalimantan Integrated Laboratory Building is going to build using reinforced concrete structure. Reinforced concrete structure is one kind of structural type using combination of concrete and rebar material with the intention of bearing loads and forces (axial, shear and moment) of the building other building elements such as brick walls as a component to divide each space in the building according to their respective functions (Amalia, 2015) (Amalia et al. 2017). The planning of the building structure of the lab has not yet taken into account the infilled brick walls as one of the structural elements and is only considered as an architectural component.

Filling walls in buildings during planning are often considered as non-structural elements that are not included in the calculation of the structure and are considered as an evenly distributed load on the slabs and beams so that they are not planned and calculated as one of the components that bear the working loads on the building structure (Pujol et al., 2010).

Several past studies stating that reinforced concrete portals with infill walls affect the actual strength and stiffness of buildings, affected by lateral loads, and have a significant role in the overall building behavior such as being able to reduce displacement of structures, inter-story drifts and increase the stiffness of the building model and are influenced by the type of material used for the infilled wall. (Dorji, 2009) This proves that the structural behavior modeled as an open frame portal with structures with infill walls will be different (Abd-Elhamed et al., 2015).

The influence of the presence of infill walls in the portal structure model is also generally able to reduce the magnitude of the bending moment and shear forces that occur in column elements on the first floor of the building structure up to 2.7 times smaller than structures that are modeled as open portals without taking into account the presence of infill walls (Sankhla et al., 2016).

One analysis model commonly used in infill wall analysis is the equivalent compressive diagonal strut model. Modeling of the infill wall as an equivalent compressive diagonal strut is to model the wall as a solid round diagonal bracing with material characteristics similar to concrete material so that portals with infill walls will be considered as portals with bracing (Dewi, 2011).

This research was carried out by comparing the structure of the Lab building modeled as an open frame model with an equivalent diagonal strut compressive (reinforced frame with infill wall as diagonal bracing) model. Both of these models are chosen to compare the forces that occur in each type of structure, the amount of displacement and the final design of the cross section of the main structural components in each model.

The purpose of conducting a comparative study of modeling an open frame building structure with a diagonal model is to:

1. Compare the force values in moment, shear, axial and torque of the main structural elements (beams, columns and slabs) in each structural model.

2. Compare the value of displacement in each structure model.

3. Compare the final dimensions of the cross-section of the main structural elements (beams, columns and slabs) in each model 


\section{Methods}

Comparative study of open frame building structure construction with diagonal press using ITK Integrated Laboratory planning data in the form of floor plans and material data used. The following are the stages of the research methods carried out.

\subsection{Literature Review}

This stage is carried out to conduct a search and understanding of the literature relating to the analysis of infill wall structures. One of the literatures used to determine the bracing dimensions, while the reference structure planning refers to SNI 2847: 2013, SNI 1729: 2015, SNI 1726: 20152012 and SNI 1727: 2013.

\subsection{Data Collection}

The planning data used in this study are the structural plan, concrete compressive strength, steel reinforcement quality, compressive strength of hebel light brick material and structural steel quality.

\subsection{Preliminary Design}

Initial planning is carried out to determine the initial dimensions of beams, columns and slabs that will be modeled in the SAP2000 assist program. Calculation of initial dimensions refers to SNI 2847: 2013 for concrete elements and SNI 1729: 2015 for steel elements. The dimensions of the beam for a simple pedestal calculated using following equation:

$$
h_{\text {min }}=\frac{L}{16} \times\left(0,4+\frac{f_{y}}{700}\right) \text { and } b_{\min }=\frac{2}{3} \times h_{\text {min }}
$$

$h_{\min }=$ minimum height of beam (m);

$L \quad=$ beam span $(\mathrm{m})$;

$f_{y} \quad=$ strength when rebar yields $(\mathrm{MPa})$;

$b_{\min } \quad=$ minimum width of beam $(\mathrm{m})$.

The initial dimensions of the column cross-section can be determined using the following equation:

$$
P=0.1 \times A_{g} \times f_{c}{ }^{\prime}
$$

$P \quad=$ load combination acting on column $(\mathrm{N})$;

$f_{c}^{\prime} \quad=$ concrete's compressive strength $(\mathrm{MPa})$;

$A_{g} \quad=$ column cross-sectional area $\left(\mathrm{mm}^{2}\right)$.

The initial dimensions of the slab cross section can be determined using the following equation:

$$
h_{\min }=\frac{L_{n}\left(0,8+\frac{f y}{1500}\right)}{36+9 \beta} \geq 90 \mathrm{~mm}
$$

$h_{\min }=$ minimum cross section thickness $(\mathrm{mm})$;

$L_{n} \quad=$ the longest span of the slab (mm);

$f_{y} \quad=$ yielding strength of reinforcing steel $(\mathrm{MPa})$;

$\beta \quad=$ ratio of the longest slab span and the shortest slab.

The diameter of the compressed bracing used as the wall fill equivalent can be calculated with the following equation (Dewi, 2011): 


$$
\begin{aligned}
& \lambda=\left(\frac{5}{4}+\frac{3}{2} v\right) \frac{W_{b}}{H_{b}}+\left(2+\frac{7}{4} v\right) \frac{H_{b}}{W_{b}}+\left(2+\frac{3}{2} v\right) \frac{H_{b}^{3}}{W_{b}^{3}} \\
& L_{d}=\sqrt{W_{b}^{2}+H_{b}^{2}} \\
& \phi=\tan ^{-1}\left(\frac{H_{b}}{W_{b}}\right) \\
& A_{d}=\frac{L_{d} \times T_{b}}{\lambda \times \cos ^{2} \phi} \\
& D=\sqrt{\frac{4 \times A_{d}}{\pi}}
\end{aligned}
$$

$\lambda \quad=$ thickness coefficient diagonal determinant of compressive diameter;

$W_{b} \quad=$ width of filler wall $(\mathrm{m})$;

$H_{b} \quad=$ height of filler wall (m);

$v \quad=$ poisson value of the hebel wall material filling ratio is 0.25 (Patre et al, 2016);

$\phi \quad=$ angle formed between the infill wall and the columns and beams;

$A_{d} \quad=$ area of diagonal cross section of press bracing for circle;

$D \quad=$ diagonal cross section of press bracing $(\mathrm{m})$.

\subsection{Loads Analysis}

This stage is carried out to determine the load acting on the structure in the form of dead load, live load and environmental burden in accordance with SNI 1727: 2013 and SNI 1726: 2012.

\subsection{Structure Modelling and Analysis}

Structural modeling is done using the SAP2000 assist program. The structural model made is an open frame model and a diagonal press model with a cross section that has been previously calculated. After being modeled, then the model is run to find out the value of the force in moment, shear, axial and torque as well as displacement.

\subsection{Section and Reinforcement Design}

This stage is carried out to plan the dimensions of the cross-section use and reinforcement requirements according to the force in the SAP2000 output results on the elements of columns, beams and reinforced concrete slabs.

\subsection{Structure Evaluation and Analysis}

This stage is carried out to check the nominal capacity of moments, shear, axial and torque with the conformity of the requirements in SNI 2847: 2013. The discussion is based on the results of the analysis and calculations that have been done.

\subsection{Conclusion}

Conclusions are drawn after modeling, calculation and analysis in accordance with the formulation of the problem presented.

The flow diagram of the stages of conducting a comparative study is shown in Figure 1 as follows: 


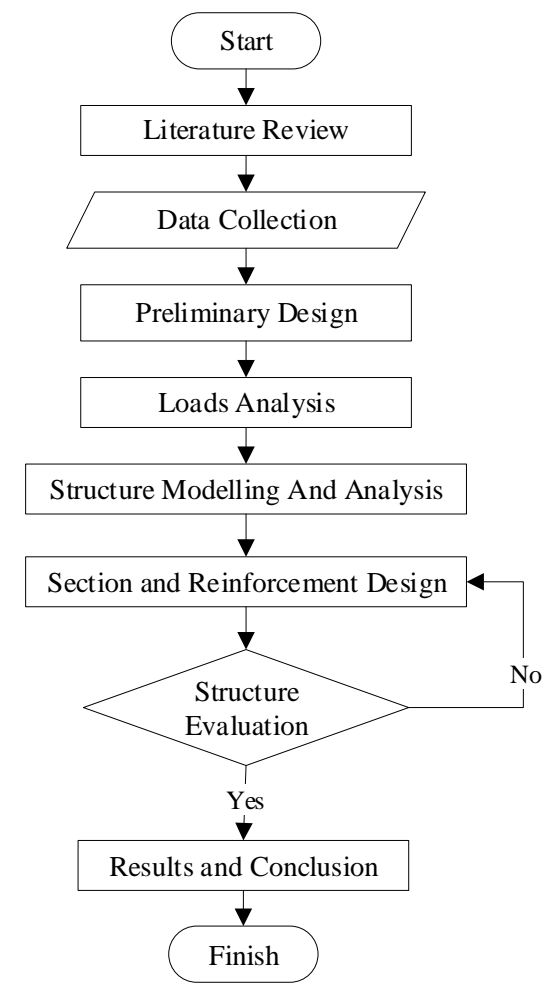

Figure 1: Research Process Flowchart

\section{Result and discussion}

\subsection{General Data}

General data used in this comparative study in the form of material characteristics and floor plans used are:
a. Steel grade
b. Concrete grade
: BJ-37 ( $\mathrm{f}_{\mathrm{y}}=240 \mathrm{MPa}$ and $\left.\mathrm{f}_{\mathrm{u}}=370 \mathrm{MPa}\right)$
c. Deformed rebar
: K-300 (f $\left.{ }^{\prime}=24.9 \mathrm{MPa}\right)$
d. Plain rebar
: BJTD-39 $\left(\mathrm{f}_{\mathrm{y}}=390 \mathrm{MPa}\right)$
e. Infilled wall type
: BJTP-24 $\left(\mathrm{f}_{\mathrm{y}}=240 \mathrm{MPa}\right)$
f. Hebel grade
: lightweight brick hebel AAC
g. Building function
: $5 \mathrm{MPa}$
h. Number of floors
: laboratory for campus building
i. Floor height
: 3 floors
: 4.25 meter

The structure plan used in this comparative study is shown in Figure 2:

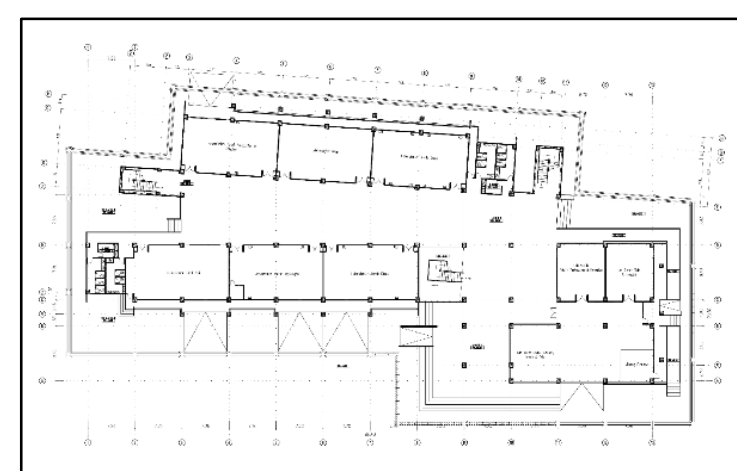

(a)

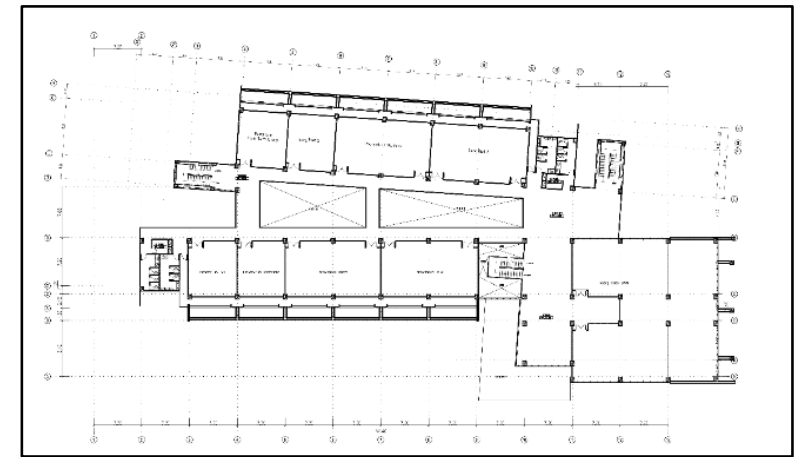

(b)

Figure 2: (a) First floor and (b) Second and third floor plan of ITK Integrated Lab 


\subsection{Preliminary Design}

The cross section used in this comparative study is based on the results of preliminary design calculations. The cross-section recapitulation used for column, slab and beam elements is shown in Table 1, Table 2, and Table 3:

Table 1: Summary of coloumn dimension

\begin{tabular}{llll}
\hline No. & \multicolumn{1}{c}{ Lantai } & B $(\mathbf{m})$ & H $(\mathbf{m})$ \\
\hline A. & Exterior Column K1 & & \\
1. & $1^{\text {st }}$ Floor & 0.55 & 0.55 \\
2. & $2^{\text {nd }}$ Floor & 0.45 & 0.45 \\
3. & $3^{\text {rd }}$ Floor & 0.20 & 0.20 \\
B. & Exterior Column K2 & & \\
1. & $1^{\text {st }}$ Floor & 0.70 & 0.70 \\
2. & $2^{\text {nd }}$ Floor & 0.55 & 0.55 \\
3. & $3^{\text {rd }}$ Floor & 0.25 & 0.25 \\
C. & Interior Column K3 & & \\
1. & $1^{\text {st }}$ Floor & 0.80 & 0.80 \\
2. & $2^{\text {nd }}$ Floor & 0.65 & 0.65 \\
3. & $3^{\text {rd }}$ Floor & 0.25 & 0.25 \\
\hline
\end{tabular}

The cross-section used for beam elements based on preliminary design results is shown in the following table:

Table 2: Summary of beam dimension

\begin{tabular}{|c|c|c|c|c|}
\hline \multirow{2}{*}{ No. } & \multirow{2}{*}{ Floor } & \multirow{2}{*}{ Beam Type } & \multicolumn{2}{|c|}{ Dimension (cm) } \\
\hline & & & B & $\mathbf{H}$ \\
\hline \multirow[t]{5}{*}{1.} & $1^{\text {st }}$ Floor & Primary Tie Beam X & 30 & 50 \\
\hline & & Primary Tie Beam Y & 30 & 50 \\
\hline & & Secondary Tie Beam X & 30 & 50 \\
\hline & & Secondary Tie Beam Y & 30 & 50 \\
\hline & & Tie Beam Alley & 30 & 40 \\
\hline \multirow[t]{8}{*}{2 . } & $2^{\text {nd }}$ Floor and & Main Beam X & 30 & 50 \\
\hline & $3^{\text {rd }}$ Floor & Main Beam Y & 30 & 50 \\
\hline & & Secondary Beam X & 30 & 50 \\
\hline & & Secondary Beam Y & 30 & 50 \\
\hline & & Cantilever Beam BC1 & 40 & 60 \\
\hline & & Cantilever Beam BC2 & 20 & 30 \\
\hline & & Listplank Beam & 30 & 40 \\
\hline & & Alley Beam & 30 & 40 \\
\hline \multirow[t]{10}{*}{3.} & Roof & Main Beam X & 30 & 50 \\
\hline & & Main Beam Y & 30 & 50 \\
\hline & & Secondary Beam X & 30 & 50 \\
\hline & & Secondary Beam Y & 30 & 50 \\
\hline & & Cantilever Beam BC1 & 50 & 70 \\
\hline & & Cantilever Beam BC2 & 20 & 30 \\
\hline & & Listplank Beam & 30 & 40 \\
\hline & & Alley Beam & 30 & 40 \\
\hline & & Ringbalk X & 30 & 40 \\
\hline & & Ringbalk Y & 30 & 50 \\
\hline
\end{tabular}

The cross-section thickness used for slab elements based on preliminary design results is shown in the following table: 
Table 3: Summary of slab thickness dimensions

\begin{tabular}{lll}
\hline No. & \multicolumn{1}{c}{ Slab Type } & \multicolumn{1}{c}{ Thickness } \\
\hline 1. & Floor Slabs & $120 \mathrm{~mm}$ \\
2. & Roof Slabs & $100 \mathrm{~mm}$ \\
\hline
\end{tabular}

\subsection{Loads Analysis}

Loading analysis was carried out in accordance with SNI 1727: 2013 and SNI 1726: 2012. Dead load is a burden caused by the weight of the structure including SIDL (Super Imposed Dead Load). Dead load and SIDL acting on the structure are shown in the following table:

Table 4: Summary of dead loads and SIDL

\begin{tabular}{clll}
\hline No. & \multicolumn{1}{c}{ Dead Loads and SIDL } & \multicolumn{1}{c}{ Unit Weight } \\
\hline 1. & Reinforced Concrete & $2400.0 \mathrm{~kg} / \mathrm{m}^{3}$ \\
2. & Structural Steel & $7850.0 \mathrm{~kg} / \mathrm{m}^{3}$ \\
3. & Galvanum Roofing & 10.0 & $\mathrm{~kg} / \mathrm{m}^{2}$ \\
4. & Polycarbonate Roofing & 1.7 & $\mathrm{~kg} / \mathrm{m}^{2}$ \\
5. & Hebel Brick Distributed Load & 115.6 & $\mathrm{~kg} / \mathrm{m}^{2}$ \\
6. & Hebel AAC & 550.0 & $\mathrm{~kg} / \mathrm{m}^{3}$ \\
7. & Ceiling Hooks & 7.0 & $\mathrm{~kg} / \mathrm{m}^{2}$ \\
8. & Ceiling & 11.0 & $\mathrm{~kg} / \mathrm{m}^{2}$ \\
9. & Mechanical, Electrical and Plumbing & 40.0 & $\mathrm{~kg} / \mathrm{m}^{2}$ \\
10. & Concrete Rebate & 21.0 & $\mathrm{~kg} / \mathrm{m}^{2}$ \\
11. & Ceramics Tile & 24.0 & $\mathrm{~kg} / \mathrm{m}^{2}$ \\
\hline
\end{tabular}

Live workload caused by the function of each room and floor used is shown in Table 5:

Table 5: Summary of live loads

\begin{tabular}{clll}
\hline No. & \multicolumn{1}{c}{ Room } & \multicolumn{1}{c}{ Loads Type SNI 1727:2013 } & \multicolumn{1}{c}{ Loading } \\
\hline 1. & Roof & Roof Live Load & $0.96 \mathrm{kN} / \mathrm{m}^{2}$ \\
2. & Auditorium & $\begin{array}{l}\text { Stadium and arena/stands with chairs tied to } \\
\text { the floor }\end{array}$ & $4.79 \mathrm{kN} / \mathrm{m}^{2}$ \\
3. & Classroom & Classroom live load & $1.92 \mathrm{kN} / \mathrm{m}^{2}$ \\
4. & Computer Laboratory & Computer room live load & $4.79 \mathrm{kN} / \mathrm{m}^{2}$ \\
5. & Laboratory & Operating theaterand laboratory live load & $2.87 \mathrm{kN} / \mathrm{m}^{2}$ \\
6. & Lobby and corridor & First floor corridor live load & $4.79 \mathrm{kN} / \mathrm{m}^{2}$ \\
7. & Stairs & Stairs and exit & $4.79 \mathrm{kN} / \mathrm{m}^{2}$ \\
8. & Stairs' Railing & Raling and stair handrail system & $0.89 \mathrm{kN}$ \\
9. & Balcony & Balcony and deck & $1.5($ Service Load) \\
10. & Office room & Office space access floor system & $2.40 \mathrm{kN} / \mathrm{m}^{2}$ \\
11. & Lobby and corridor & Corridor live load above first floor & $3.83 \mathrm{kN} / \mathrm{m}^{2}$ \\
\hline
\end{tabular}

\subsection{Structure Modeling}

Structural modeling was modelled using the SAP2000 program. The elements being modeled were beams, columns and slabs. In this modeling, the infill wall was inserted as an even SIDL load on the beam. The results of the ITK Integrated Frame Laboratory open frame model in the SAP2000 assistance program according to the results of preliminary design calculations are shown in Figure 3: 


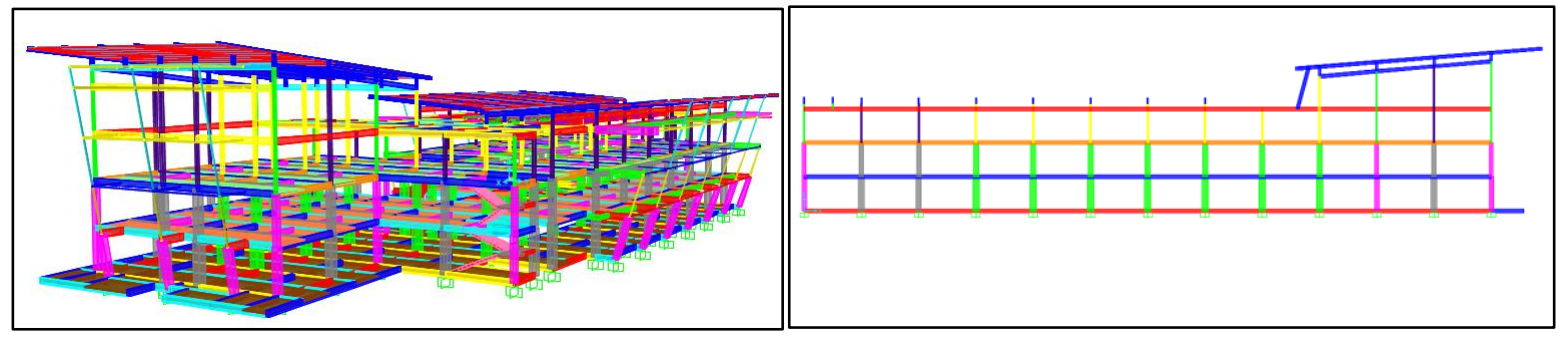

Figure 3: Modelling Open Frame in SAP2000

Structural modeling as a compressive bracing diagonal frame was calculated by assuming the fill wall functions as a diagonal press with similar lightweight concrete material with compressive strength and specific gravity following the characteristics of lightweight brick material. Examples of calculations to find the equivalent of a fill wall into a diagonal rod press for a wall with fill wall thickness, $\mathrm{t}=150$ $\mathrm{mm}$, wall height, $\mathrm{H}=4250 \mathrm{~mm}$ and wall width, $\mathrm{W}=8400 \mathrm{~mm}$ as follows: for the equivalent wall fill constant was calculated as follows:

$$
\lambda=\left(\frac{5}{4}+\frac{3}{2}(0,25)\right) \frac{8400}{4250}+\left(2+\frac{7}{4}(0,25)\right) \frac{4250}{8400}+\left(2+\frac{3}{2}(0,25)\right) \frac{4250^{3}}{8400^{3}}=4,39
$$

Next, the length of the slope of the compressed diagonal bar and the angle formed were calculated by the following equation:

$$
\begin{aligned}
& L_{d}=\sqrt{W_{b}^{2}+H_{b}^{2}}=\sqrt{8400^{2}+4250^{2}}=9413,95 \mathrm{~mm}^{2} \\
& \phi=\tan ^{-1}\left(\frac{H_{b}}{W_{b}}\right)=\tan ^{-1}\left(\frac{4250}{8400}\right)=26,83^{\circ}
\end{aligned}
$$

The area of equivalent wall fill could be calculated with the following equation:

$$
A_{d}=\frac{L_{d} T_{b}}{\lambda \cos ^{2} \phi}=\frac{9413,95 \times 150}{4,39 \times \cos ^{2}(26,83)}=403653 \mathrm{~mm}^{2}
$$

The dimensions of the bracing section were assumed to be circular, so the bracing diameter was calculated by the following equation and a bracing diameter on the wall is used with a value of $0.72 \mathrm{~m}$.

$$
D=\sqrt{\frac{4 A_{d}}{\pi}}=\sqrt{\frac{4(403653)}{\pi}}=717,08 \mathrm{~mm}=0,72 \mathrm{~m}
$$

With compressive strength $\mathrm{f}_{\mathrm{m}}=5 \mathrm{MPa}$, the modulus of elasticity of the light brick can be calculated according to the equation for the infill wall with the concrete constituent material as follows (Paulay and Priestley, 1992):

$$
E_{m}=1000 f^{\prime}{ }_{m}=1000 \times 5=5000 \mathrm{MPa}
$$

By using specific gravity of $550 \mathrm{~kg} / \mathrm{m}^{3}$ and Poisson ratio of 0.25 , the AAC lightweight brick material can be defined in SAP2000 program for models with compressed diagonal shown in Figure 4. 


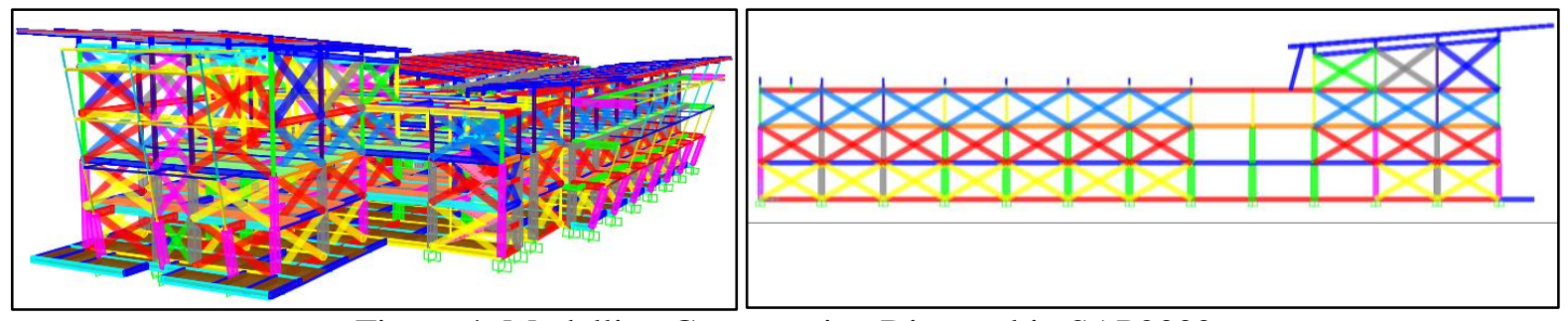

Figure 4: Modelling Compression Diagonal in SAP2000

\subsection{Comparison of Internal Force and Section Design Beam Elements}

The infill wall is a building component that is generally regarded as an architectural element that does not function to carry structural loads so that it is only modeled as an even load on the beam element. In this comparative study, the ITK Integrated Laboratory building structure modeling was carried out on the SAP2000 assistive program in two models, namely the open frame model and the building model with a filler wall as a diagonal bracing press equivalent. In general, the three models showed different results, both the results of internal force analysis, displacement of the structure (displacement) and also on the design of the main structure. Comparison of forces in moment, shear and torque on beam elements whose differences were relatively prominent as shown in Table 6 and Figure 5.

\subsection{Comparison of Bending Moment and Torsion}

From Table 6, it could be seen elements that have different bending moment styles that tend to be striking. As in the Transverse Main Beam on the 3rd Floor. The moment value on the open frame tended to be greater than the diagonal press value which is respectively $-317.43 \mathrm{kN}$ and $-279.26 \mathrm{kN}$. This was according to the concept which states that the infill wall in the structural model can increase the structural stiffness and strength (Catagay et al., 2010) (Frapanti, 2018). The difference in force in this also resulted in differences in cross-sectional design and reinforcement design on the beam being reviewed. The cross section and reinforcement design for the Transverse Main Beams on the 3rd Floor in a row for each model are:
a. Open Frame (OF) model
: 40/60 with reinforcements (5D22 dan 3D22)
b. Compressive Bracing (CB) model : 30/60 with reinforcements (5D22 dan 4D22) 
Table 6: Comparison of internal force of beam element

\begin{tabular}{|c|c|c|c|c|c|c|c|}
\hline No. & Element & $\begin{array}{c}\text { OF } \\
\mathbf{M} \\
{[\mathrm{kNm}]}\end{array}$ & $\begin{array}{c}\text { DT } \\
\text { M } \\
{[\mathrm{kNm}]} \\
\end{array}$ & $\begin{array}{c}\text { OF } \\
\mathbf{V} \\
{[\mathbf{k N}]} \\
\end{array}$ & $\begin{array}{c}\text { DT } \\
\mathbf{V} \\
{[\mathrm{kN}]} \\
\end{array}$ & $\begin{array}{c}\text { OF } \\
\text { T } \\
{[\mathrm{kNm}]}\end{array}$ & $\begin{array}{c}\text { DT } \\
\text { T } \\
{[\mathrm{kNm}]} \\
\end{array}$ \\
\hline $\bar{A}$ & $\mathbf{1}^{\text {st }}$ Floor & & & & & & \\
\hline 1 & Prim. Tie Beam Y & -344.32 & -319.71 & 258.16 & -180.47 & -45.61 & -52.66 \\
\hline 2 & Sec. Tie Beam X & -384.94 & -381.83 & -171.09 & -169.78 & -61.68 & -61.7 \\
\hline 3 & Tie Beam Alley & -94.89 & -85.78 & -76 & -71.04 & -31.7 & -29.99 \\
\hline B & $2^{\text {nd }}$ Floor & & & & & & \\
\hline 1 & Main Beam X & -267.49 & -247.25 & -171.25 & -157.45 & 75.51 & 55.54 \\
\hline 2 & Main Beam Y & -345.02 & -340.56 & 234.49 & 192.07 & -61.69 & -62.36 \\
\hline 3 & Sec. Beam X & -108.61 & -106.72 & 92.5 & -85.33 & -35.88 & -19.58 \\
\hline 4 & Sec. Beam Y & -165.08 & -136.17 & -106.27 & 101.07 & -34.81 & -32.21 \\
\hline 5 & Listplank Beam & -43.9 & -43.02 & -40.25 & -34.55 & -130.88 & -120.81 \\
\hline $\mathrm{C}$ & $3^{\text {rd }}$ Floor & & & & & & \\
\hline 1 & Main Beam X & -317.43 & -279.26 & 201.55 & 175.74 & -45.62 & 47.79 \\
\hline 2 & Main Beam Y & -381.36 & -338.67 & -250.86 & -195.42 & -78.57 & -76.44 \\
\hline 3 & Listplank Beam & -47.15 & -45.44 & 66.12 & -35.34 & -138.72 & -126.11 \\
\hline D & Roof & & & & & & \\
\hline 1 & Main Beam X & -182.77 & -172.86 & 108.13 & 103.87 & 64.66 & 54.98 \\
\hline 2 & Main Beam Y & -212.54 & -185.58 & 102.97 & 122.96 & 38.76 & 29.17 \\
\hline 3 & Sec. Beam X & -104.2 & -64.12 & 50.04 & -37.55 & -13.49 & -11.1 \\
\hline 4 & Sec. Beam Y & -119.87 & -105.83 & -325.92 & -267.89 & -113.02 & -68.84 \\
\hline 5 & Ringbalk Y & -161.73 & -157.54 & -101.39 & -96.96 & 72.33 & 69.66 \\
\hline
\end{tabular}

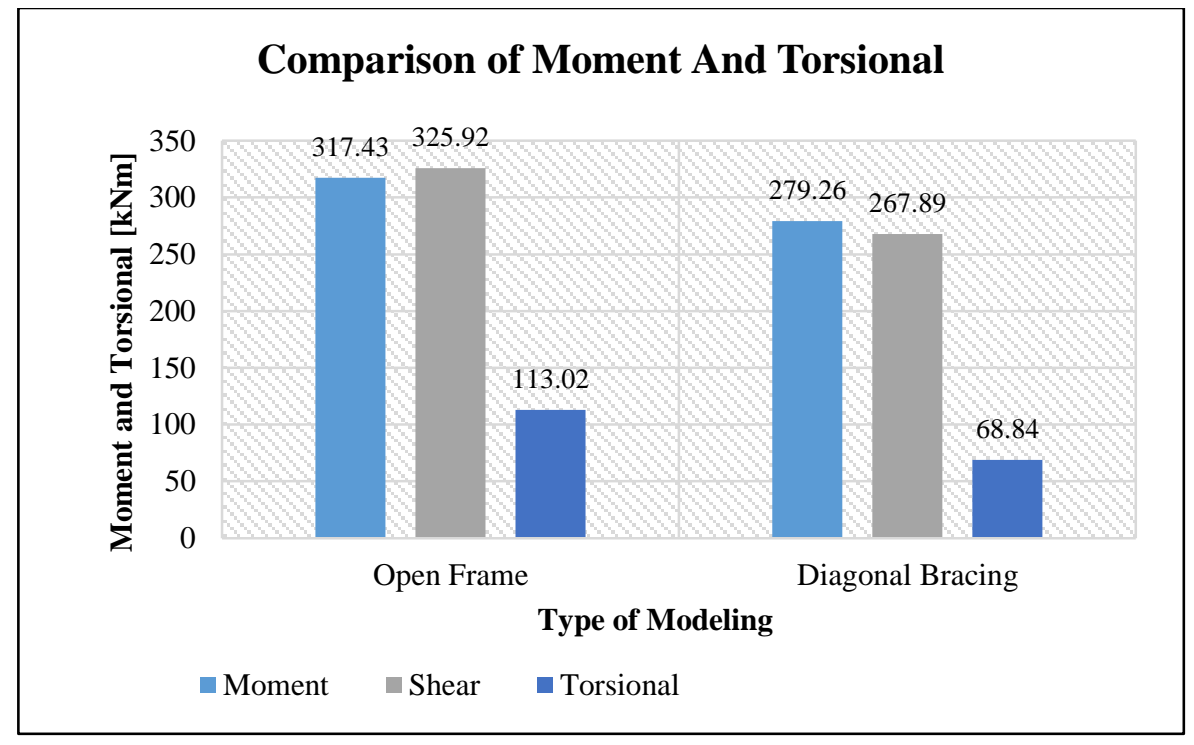

Figure 5: Comparison of Beam Elements' Internal Force

\subsection{Comparison of Shear Force}

From Figure 5, the elongated Secondary Beam element on the Roof Floor of the open frame model were larger, equals to $-325.93 \mathrm{kN}$, whereas in the diagonal model the press was $-267.89 \mathrm{kN}$. This proved that the infill wall also contributed to resist the shear forces that occur in the beam. The difference in shear force could also affect the design of the planned shear reinforcement on the beam so that it was more economical. In the review beam design, the difference was in the number of legs contained in the shear reinforcement as follows:
a. Open Frame (OF) model
: 40/70 dimension, shear reinforcement (3Ø10-100)

b. Compressive Bracing (CB) model : 40/70 dimension, shear reinforcement (2Ø10-100) 


\subsection{Comparison of Torsional Force}

Furthermore, the torque force that occurs in the beam also tended to have different values. The torque or torque moment on the beam often worked in tandem with the moment and also shear and in some planning, the effect of torque could be more decisive. From Table 6, relatively large differences occurred in the Secondary Roof Beams with an open frame value of $-113.02 \mathrm{kNm}$ and a diagonal press of $-68.84 \mathrm{kNm}$. In this condition, the final cross-section design did not differ because the crosssectional dimension provided can withstand both the torque value of the open frame and the compressive diagonal.

a. Open Frame (OF) model $\quad$ :40/70 dimension, torsional reinforcement (3D22 and 3D22)

b. Compressive Bracing (CB) model : 40/70 dimension, torsional reinforcement (3D22 dan 3D22)

\subsection{Comparison of Internal Force and Section Design Coloumn Element}

Differences in force in and cross-section of columns taken review column K1 Floor 2 of the axial force and bending moment that occurred. From the two models, the smallest axial force was found in the diagonal compressive model while for the bending moment also on the diagonal compressive model shown in Table 7 and Figure 6 as follows:

Table 7: Comparison of column's internal force

\begin{tabular}{|c|c|c|c|c|}
\hline \multicolumn{2}{|c|}{ K1 $2^{\text {nd }}$ Floor } & $\mathbf{P}$ & M2 & M3 \\
\hline \multirow{2}{*}{ Open Frame } & Max & 141.40 & 161.51 & 160.42 \\
\hline & Min & -959.11 & -169.03 & -122.61 \\
\hline \multirow{2}{*}{ Diagonal Bracing } & $\operatorname{Max}$ & 64.28 & 112.44 & 111.39 \\
\hline & Min & -777.36 & -112.43 & -89.03 \\
\hline
\end{tabular}

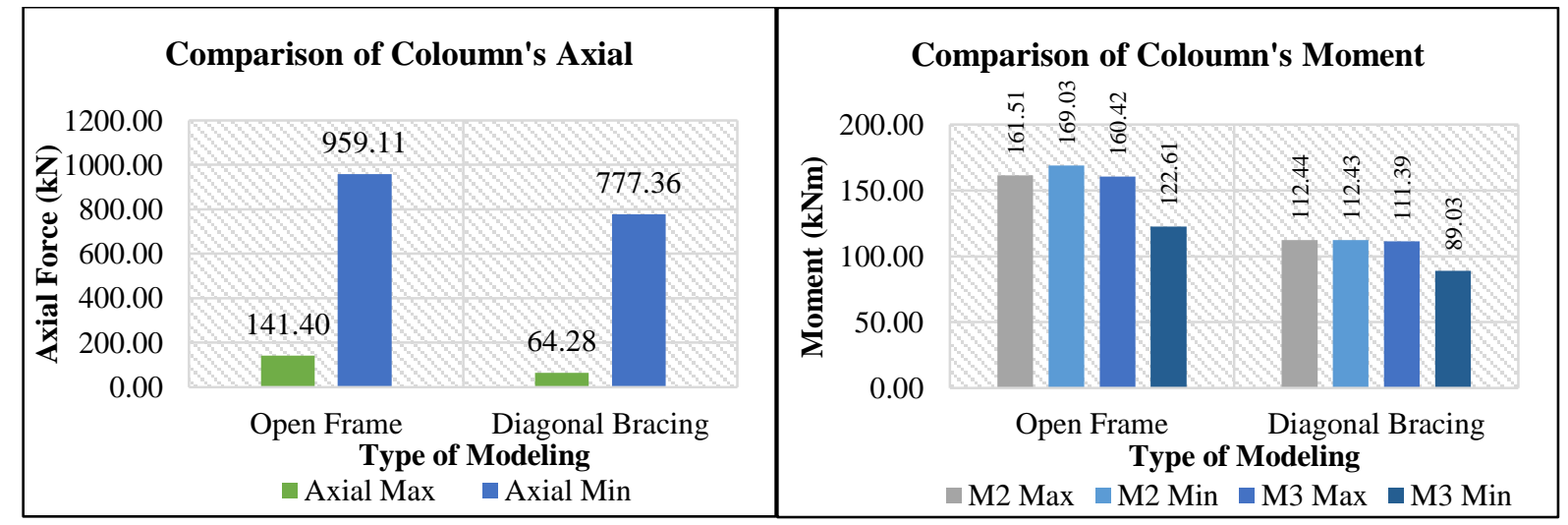

$\begin{array}{ll}\text { (a) Axial Force } & \text { (b) Bending Moment }\end{array}$

Figure 6: Comparison of Beam Elements' Internal Force

The difference in style in this affected the dimensions of the planned column because the design of the cross section and column reinforcement were influenced by the interaction between axial and bending moments. Dimension column K1 Floor 2 of each model:

a. Open Frame (OF) model : 50/50 dimension; reinforced with 20-D22 bar

b. Compressive Bracing (CB) model : 50/50 dimension; reinforced with 16-D22 bar

\subsection{Comparison of Internal Force and Section Design Slab Element}

On the slab elements, a slab review on the 2 nd floor was taken for each model analyzed. The internal force compared to the slab element was the bending moment in the transverse direction (M11) and elongated slab (M22) as follows: 
Table 8: Comparison of slab's internal force

\begin{tabular}{llll}
\hline \multicolumn{2}{c}{$\mathbf{2}^{\text {nd }}$ Floor Slab } & \multicolumn{1}{c}{ M11 } & \multicolumn{1}{c}{ M22 } \\
\hline \multirow{2}{*}{ Open Frame } & Max & 81.12 & 135.51 \\
\multirow{2}{*}{ Diagonal Bracing } & Min & -28.03 & -22.04 \\
& Max & 75.41 & 126.74 \\
& Min & -26.22 & -21.72 \\
\hline
\end{tabular}

Based on this table, the internal forces generated by the open frame model were the largest compared to the diagonal model of pressure both at the moment M11 for the X direction and M22 for the $\mathrm{Y}$ direction. Graphically, the comparison is shown in Figure 6.

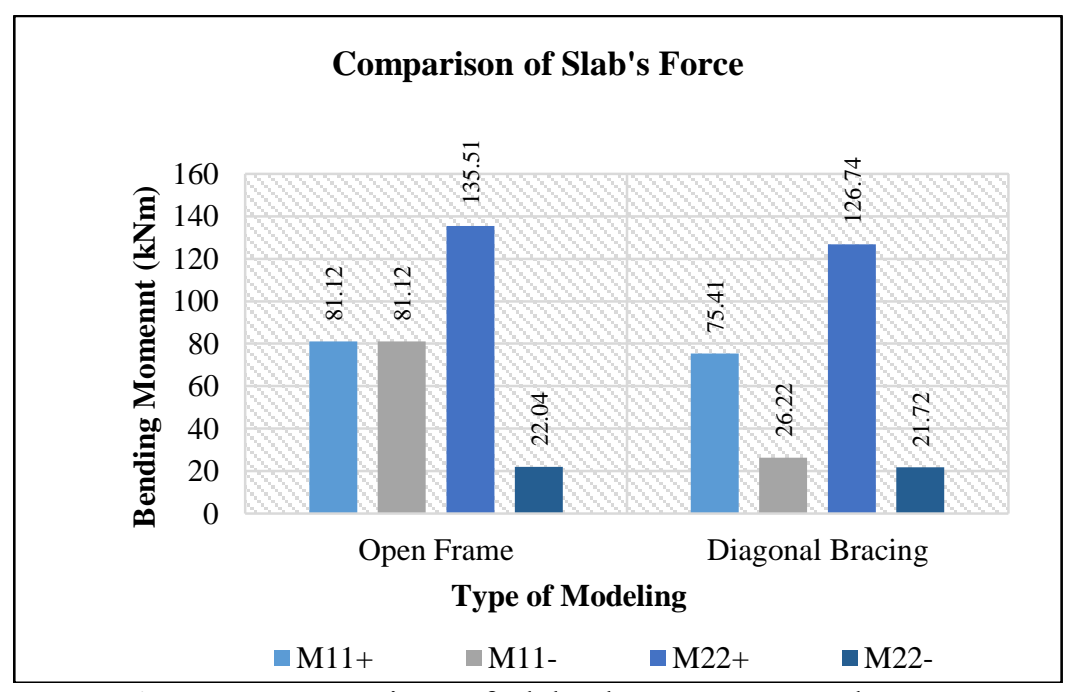

Figure 7: Comparison of Slab Elements' Internal Force

Because of the different internal forces, the thickness of the slabs and the need for reinforcement used also tend to be different. The different cross-sectional designs used as follows:

a. Open Frame Slabs' Design

Slab thickness $=190 \mathrm{~mm}$

Reinforcement $X=4 \mathrm{D} 16-300$ and 10D16-100

Reinforcement $\mathrm{Y}=4 \mathrm{D} 16-300$ and 15D16-50

b. Diagonal Bracing Slab's Design

Slab thickness $=180 \mathrm{~mm}$

Reinforcement $X=3 \mathrm{D} 16-450$ and 9D16-100

Reinforcement $\mathrm{Y}=3 \mathrm{D} 16-450$ and 15D16-50

\subsection{Comparison of Structure's Displacement}

In the comparative review of displacement in each model, the model using filler walls as diagonal bracing press had relatively smaller displacement compared to the open frame model without walls. This suggested that the presence of filler walls adds rigidity to the structure so that the behavior and performance of the structure are burdened by lateral loads such as wind loads and earthquake loads. The displacement value of the structure for the $\mathrm{X}$ direction and $\mathrm{Y}$ direction is shown in Table 9: 
Table 9: Displacement value of each floor

\begin{tabular}{|c|c|c|c|c|c|}
\hline \multirow{2}{*}{ Floor } & Height & $\begin{array}{l}\text { Open } \\
\text { Frame }\end{array}$ & $\begin{array}{c}\text { Diagonal } \\
\text { Bracing }\end{array}$ & $\begin{array}{c}\text { Open } \\
\text { Frame }\end{array}$ & $\begin{array}{c}\text { Diagonal } \\
\text { Bracing }\end{array}$ \\
\hline & {$[\mathrm{mm}]$} & [mm] & {$[\mathrm{mm}]$} & {$[\mathrm{mm}]$} & {$[\mathrm{mm}]$} \\
\hline Roof & 20700 & 151.29 & 22.17 & 130.60 & 38.12 \\
\hline 3 & 8500 & 24.53 & 1.43 & 23.06 & 1.08 \\
\hline 2 & 4250 & 7.04 & 0.94 & 9.83 & 1.77 \\
\hline
\end{tabular}

In the X Direction for the roof floor, the displacement value of the open frame and diagonal compressive models were $151.29 \mathrm{~mm}$ and $22.16 \mathrm{~mm}$, respectively. The difference of the magnitude of displacement in the direction of $X$ on the model without a wall or open frame with the model using the wall as a diagonal equivalent to $85.35 \%$. While the magnitude of the Y Direction for the roof floor, the displacement value of the open frame and diagonal press models were $130.60 \mathrm{~mm}$ and $38,118 \mathrm{~mm}$, respectively. The difference in the magnitude of displacement in the direction of $\mathrm{Y}$ in the model without open frame walls with the model using the wall as a diagonal bracing equivalent to $70.83 \%$. Graphically, the comparison is shown in Figure 7 and Figure 8:

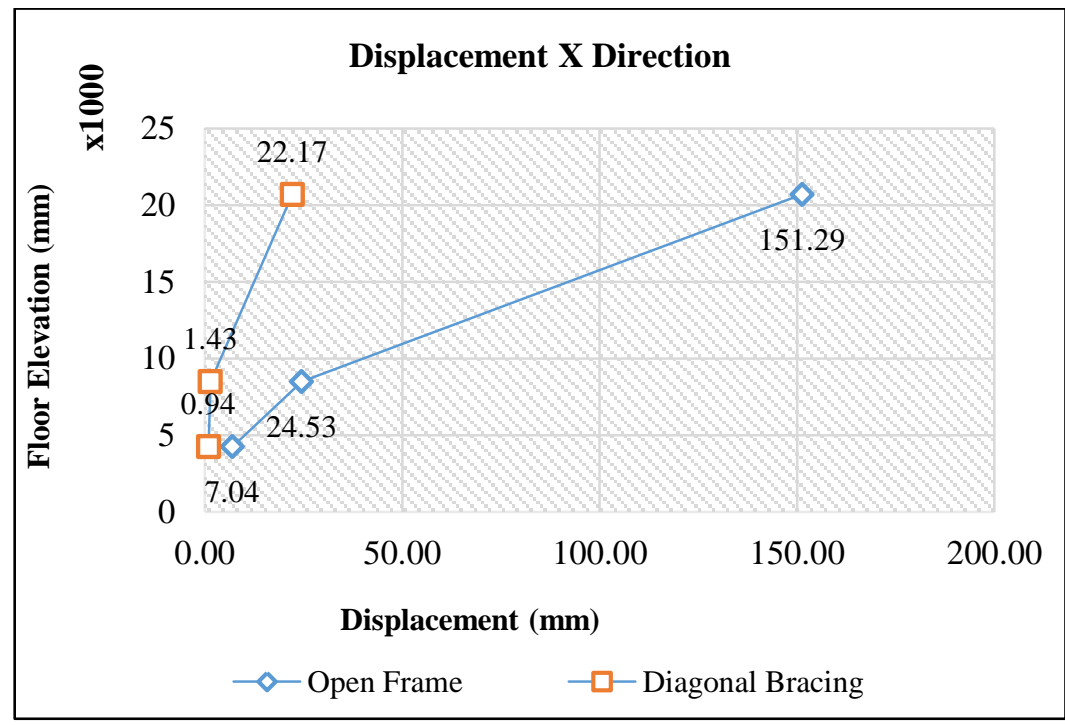

Figure 8: Structure Displacement on X Direction

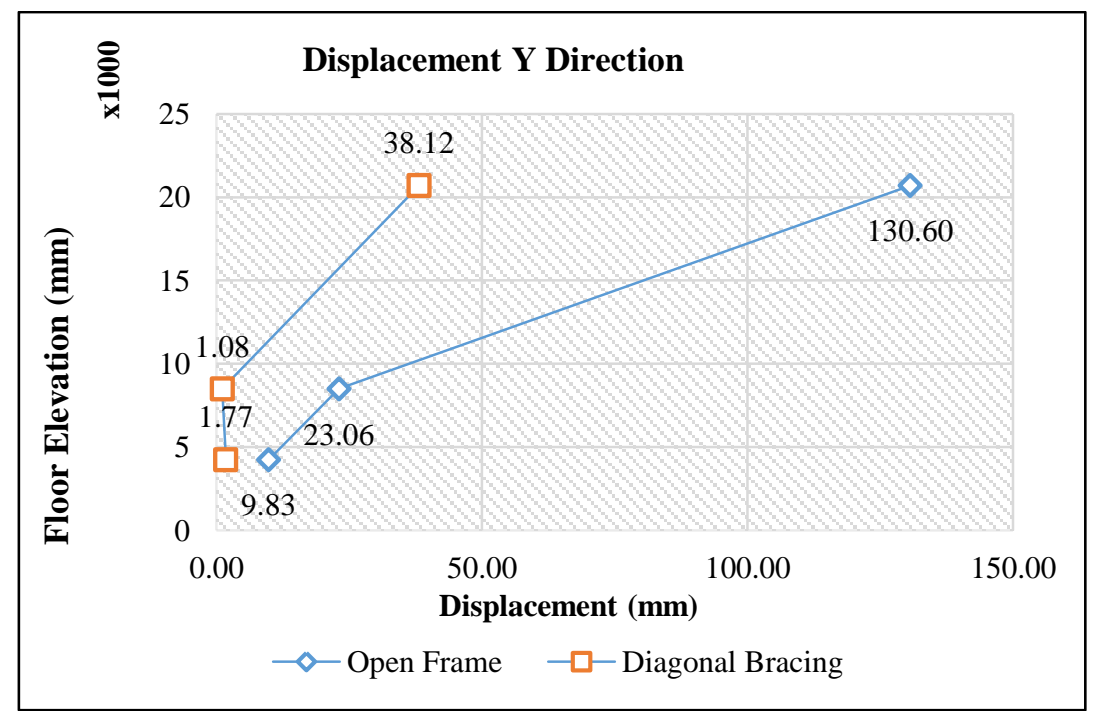

Figure 9: Structure Displacement on Y Direction 
Based on the graph, it is clear that the presence of a filler wall reduces the value of displacement. This happens because the number of elements holding more lateral loads is the main structural components such as beams, columns and slabs coupled with the equivalent of the fill wall as a diagonal bracing press and evenly distributed to these elements.

\section{Conclusion}

Open Frame Structure Modeling with Diagonal Bracing at the Integrated Laboratory of ITK, it can be concluded that:

1. Internal force analysis shows that the moment, shear, axial and torque forces of the open frame model were greater than the compressed diagonal model with a difference of $38.17 \mathrm{kNm}, 58.03$ $\mathrm{kN}, 181.75 \mathrm{kN}$ and $44.18 \mathrm{kNm}$ respectively.

2. The displacement value of the open frame model was greater than the diagonal press model with the $\mathrm{X}$ direction difference for the roof level of $85.35 \%$ and $\mathrm{Y}$ direction of $70.83 \%$.

3. The final dimension of the cross section found on the diagonal compressive model tended to be smaller that is 30/60 compared to the open frame model which is $40 / 60$ on the beam element. In the column element, the diagonal dimensions of press were 50/50 with reinforcement 16-D22 and in open frame is 50/50 with reinforcement 20-D22. Thick diagonal slab press was also smaller that is $180 \mathrm{~mm}$ compared to the open frame model of $190 \mathrm{~mm}$.

Overall, modeling the infill wall can have a positive impact on structural modeling so that the resulting cross section is more efficient than without a wall.

\section{References}

Abd-Elhamed, A. and Mahmoud, S. (2015) 'Effect-of-infill-walls-on-response-of-multi-storey-reinforcedconcrete-structure', International Journal of Civil, Environmental, Structural, Construction and Architectural Engineering, Vol. 9, No. 5: 514-518.

Amalia, A. R. and Iranata, D. (2017) 'Comparative study on diagonal equivalent methods of masonry infill panel' in Proceedings of the $3^{\text {rd }}$ International Conference on Engineering, Technology, and Industrial Application, Surakarta, Indonesia: ICETIA.

Amalia, R. (2015) Studi Perbandingan Perilaku Struktur Eccentrically Braced Frames Inverted V dan Eccentrically Braced Frames Inverted Y terhadap Beban Lateral Gempa (Undergraduate Thesis), Surabaya: Institut Teknologi Sepuluh Nopember.

American Society of Civil Engineers (ASCE). (2010) Minimum Design Loads for Buildings and Other Structures: ASCE Standard ASCE/SEI 7-10. Reston, Virginia: American Society of Civil Engineers.

Applied Technology Council. ATC 40 (1996) Seismic Evaluation and Retrofit of Concrete Buildings, Redwood City: Applied Technology Council.

Badan Standardisasi Nasional (2012) SNI 1726 :2012 Tata Cara Perencanaan Ketahanan Gempa untuk Struktur Bangunan Gedung dan Non-Gedung, Bandung: Departemen Pekerjaan Umum.

Badan Standardisasi Nasional (2013) SNI 1727:2013 Beban Minimum untuk Perencanaan Bangunan Gedung dan Struktur Lain, Jakarta: Departemen Pekerjaan Umum.

Badan Standardisasi Nasional (2013) SNI 2847:2013 Persyaratan Beton Struktural untuk Bangunan Gedung, Jakarta: Departemen Pekerjaan Umum.

Badan Standardisasi Nasional (2015) SNI 1729:2015 Spesifikasi untuk Bangunan Gedung Baja Struktural, Jakarta: Departemen Pekerjaan Umum.

Cagatay, I. H., Beklen, C., and Mosalam, K. M. (2010) 'Investigation of short column effect of RC buildings: Failure and prevention', Computers \& Concrete, Vol. 7, No. 6: 523-532. 
Dewi, R. R. (2011) Studi Perilaku Model Panel Dinding Bata Pengisi pada Struktur Beton Bertulang (Undergraduate Thesis of Civil Engineering), Surabaya: Institut Teknologi Sepuluh Nopember.

Dorji, J. (2009) Seismic Performance of Brick Infilled RC Frame Structures in Low and Medium Rise Buildings in Bhutan (Thesis Master of Engineering), Brisbane: Queensland University of Technology.

Frapanti, S. (2018) 'Studi perhitungan kekakuan portal dinding bata pada bangunan bertingkat dari beberapa negara dengan pushover', Educational Building Jurnal Pendidikan Teknik Bangunan dan Sipil, Vol. 4, No. 1: $1-10$.

Patre, A. and Vairagade, L. (2016) 'Comparative analysis and design of high-rise structure using light weight infill blocks and conventional bricks', International Journal of Trend in Research and Development, Vol. 3, No. 4: 4-6.

Paulay, T. P. and Priestley, M. J. N. (1992) Seismic Design of Reinforced Concrete and Masonry Buildings, New York: John Wiley \& Sons, Inc.

Pujol, S. and Fick, D. (2010) 'The test of a full-scale three-story RC structure with masonry infill walls', Engineering Structures, Vol. 32, No. 10: 3112-3121.

Sankhla, S. S. and Bhati, D. (2016) 'A comparative study on the effect of infill walls on RCC frame structures', Journal of Mechanical and Civil Engineering, Vol. 13, No. 6: 1-8. 